\title{
The Last Interglacial in the Mediterranean as a model for the present interglacial
}

\author{
C. Zazo ${ }^{\text {a }}$, J.L. Goy ${ }^{\text {b }}$, C.J. Dabrio ${ }^{\text {c }}$, T. Bardaji ${ }^{\text {d }}$, L. Somoza ${ }^{\mathrm{e}}$ and P.G. Silva ${ }^{\mathrm{b}}$ \\ ${ }^{a}$ Departamento de Geología, Museo Nacional de Ciencias Naturales, C.S.I.C. José Gutiérrez Abascal 2, 28006-Madrid, Spain \\ ${ }^{b}$ Departamento de Geología (Geodinámica), Facultad de Ciencias, Universidad, 37008-Salamanca, Spain \\ ${ }^{c}$ Departamento de Estratigrafía, Facultad de Geología, U.C.M. and Instituto de Geología Económica C.S.I.C., 28040-Madrid, Spain \\ ${ }^{d}$ Departamento de Geología, Universidad de Alcalá de Henares, 28871-Madrid, Spain \\ ${ }^{e}$ Instituto Español de Oceanografía, Fuengirola, Málaga, Spain
}

(Received August 30, 1991; revised and accepted July 30, 1992)

\section{ABSTRACT}

Deposits of the Last Interglacial on the south and southeastern coasts of Spain are shallow marine and coastal sediments, with a warm fauna of Strombus bubonius. These units exhibit a diversity of morpho-sedimentary models controlled by the tectonic activity of the Mediterranean area, which is closely related to the approximation of Africa and Iberia during the Quaternary.

There are three well-dated peaks of maximum sea level (T-I: isotopic substage 7a, T-II: isotopic substage 5e, T-III: isotopic substage 5c). A younger episode, T-IV, probably corresponds to the isotopic substage 5a. Episodes T-II, T-III and T-IV were laid down during Last Interglacial age. In addition, three Holocene peaks of maximum sea level: $\mathrm{H}_{1}$ ca. 5100 yr B.P., $\mathrm{H}_{2}$ ca. $3500 \mathrm{yr}$ B.P. and $\mathrm{H}_{3}$ ca. $2400 \mathrm{yr}$ B.P. were found.

The three main peaks of the Last Interglacial correspond to the morpho-sedimentary Tyrrhenian units T-II, T-III and T-IV, deposited during a time span of some 45,000 years. Several smaller oscillations can be distinguished within each of these units as subunits separated by erosional surfaces. At least three of such mapable subunits were distinguished within the peak T-II (5e); each lasted ca. 10,500 yr.

As the positive oscillations of sea level $\left(\mathrm{H}_{1}, \mathrm{H}_{2}\right.$, and $\left.\mathrm{H}_{3}\right)$ recorded during the present Interglacial (Holocene) are much shorter, we infer that they are smaller-scale fluctuations (2500-1100 yr cycles) within the first oscillation (duration: ca. $10,500 \mathrm{yr}$ ) of the first Holocene peak of sea level which has not yet been completed.

In addition to changes of sea level, the vertical and lateral arrangement of morpho-sedimentary units, which can be designated as the stratigraphic architecture, depends on tectonics and oceanography, including geoidal and steric changes and coastal dynamics.

The coastal dynamics factor largely depends on the exchange of waters between the Atlantic and the Mediterranean. Maximum incursions of water coincides with warm periods (highstands) when the coastal accretion increases.

The tectonic factor greatly influences and modifies the effects of sea-level changes in the coastal areas of tectonically-active regions such as the Mediterranean. Areas with tectonic uplift will be characterized by a staircase of prograding gravelly beaches, whereas sinking areas will favour the deposition of vertically stacked sequences with coastal onlap of barrier island and lagoon deposits.

Rates of sea-level rise for the coming years of $1 \mathrm{~cm} / \mathrm{yr}$, have been suggested by some authors. These gradients greatly exceed those produced by any tectonic factor in the Spanish coast during the last $100 \mathrm{kyr}$. Shoreface erosion and transgression with landward migration of barrier islands and lagoons will occur in subsiding areas (Murcia-Alicante and Valencia), even with relatively low rates of sea-level rise (less than $0.5 \mathrm{~cm} / \mathrm{yr}$ ). Higher rates of sea-level rise $(0.5-1 \mathrm{~cm} / \mathrm{yr}$ ) will increase the transgressive trend. Areas with subsidence rates higher than $7.5 \mathrm{~cm} / \mathrm{kyr}$ (Mar Menor and Oval of Valencia) are prone to transgression and erosion of barrier islands and lagoons both in the cases of stable and rising sea levels. Risks are smaller in areas with lower rates of subsidence (La Mata, Santa Pola and Torrevieja lagoons) when a stable sea level is considered; however, any rise of sea level will trigger coastal erosion. 


\section{Introduction}

Deposits of the Last Interglacial have been recorded along the south and southeastern Spanish coast as three highstand sedimentary units. They consist of marine deposits, with a warm fauna of Strombus bubonius, commonly referred to as Tyrrhenian.

These three marine Tyrrhenian units exhibit a diversity of morpho-sedimentary models controlled by the tectonic activity of the Mediterranean area, which is closely related to the approximation of Africa and Iberia during the Quaternary. A compressional realm resulted from movements of the trans-Alboran fault (Fig. 1) which acted as a transmitter of sinistral stresses (Montenat et al., 1987). Compressional stresses decreased from south to north (Almería to Alicante, zones 4-1, Fig. 1) and generated a sequence of variable tectonic uplift because of a reduction in the absorption of the deformation. Extensional regimes active during the Quaternary occur in Valencia and Balearic Islands (zones 6 and 7, Fig. 1) because of processes of the "Valencia Trough." Quaternary extensional processes in southwestern Spain induced strong subsidence in the Guadalquivir and Cádiz areas (zone 5, Fig. 1) (Zazo et al., 1985). These phenomena

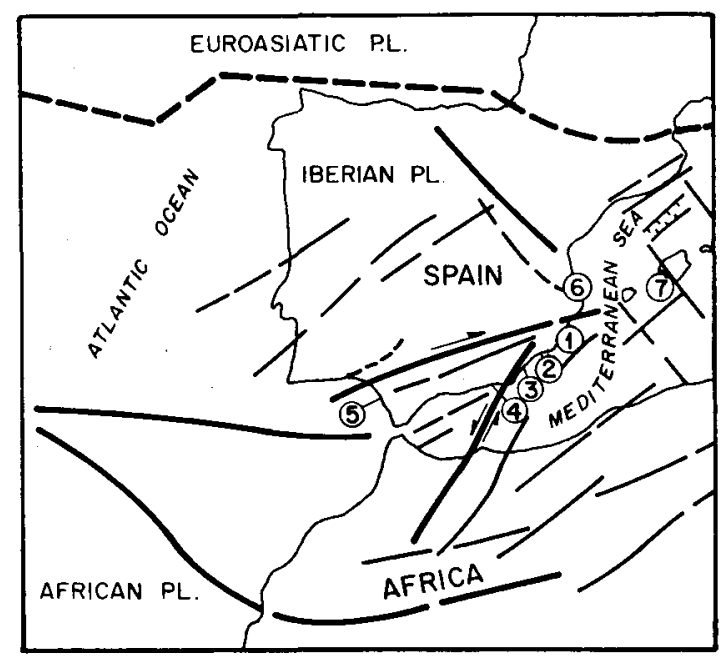

Fig. 1. Location map of the study areas $(1=$ Alicante, $2=$ Alicante-Murcia, $3=$ Cope, Murcia, $4=$ Almería, $5=$ Cádiz, $6=$ Oval of Valencia, $7=$ Balearic Islands) as related to the main tectonic structures active during the Quaternary. are related to the Cádiz-Alicante dextral fracture-line which is connected to the Azores transform fault.

Thus there is a highly-variable geodynamic pattern during the Quaternary in south Spain (Zazo et al., 1990) from areas trending to uplift with a staircase of marine terraces in Almería (Goy and Zazo, 1986) to subsiding areas both on the Atlantic side and the Oval of Valencia where large complexes of beach barriers and lagoons developed.

The studied area is important for understanding global and regional phenomena because of its proximity to the Gibraltar Strait. Two important phenomena which occurred during glacial-interglacial periods affected the deposition of marine Quaternary deposits. Firstly, migrations through the Strait of both warm fauna coming from the equatorial Atlantic Ocean and cold fauna. Secondly, the differences in the exchange of Atlantic and Mediterranean water-masses during glacial and interglacial periods (Abrantes, 1988) greatly changed the coastal processes which, in one way or another, are related to the incoming current and the clock-wise (anticyclonic) vortexes that it produces in the Alborán Sea (Somoza et al., 1991).

Sea-level highstands in the last $200 \mathrm{ka}$ in Spain, reference episodes and isotopic measurements

Four morpho-stratigraphic marine units bearing warm fauna including Strombus bubonius have been distinguished in the southeastern Spanish littoral. Distinctive criteria were geomorphological mapping, sedimentological and neotectonic studies (Goy and Zazo, 1986, 1988; Bardají et al., 1986; Somoza, 1989) coupled with isotopic measurements (Bernat et al., 1982; Brückner, 1986; Hillaire-Marcel et al., 1986; Goy et al., 1986). These episodes have been named T-I (Tyrrhenian I, age ca. $180 \mathrm{kyr}$ ), T-II (ca. $128 \mathrm{kyr}$ ), T-III (ca. 95 kyr) and T-IV. The youngest, fourth episode (TIV) has not been dated so far (Zazo and Goy, 1989).

The same units crop out in the Balearic littoral, but $S$. bubonius is present in the deposits of the two older episodes (T-I and T-II) only. In situ 
TABLE 1

Geometries and sedimentary models of Tyrrhenian marine units as related to tectonics and distance to the source of sediment (modified after Zazo et al., 1990).

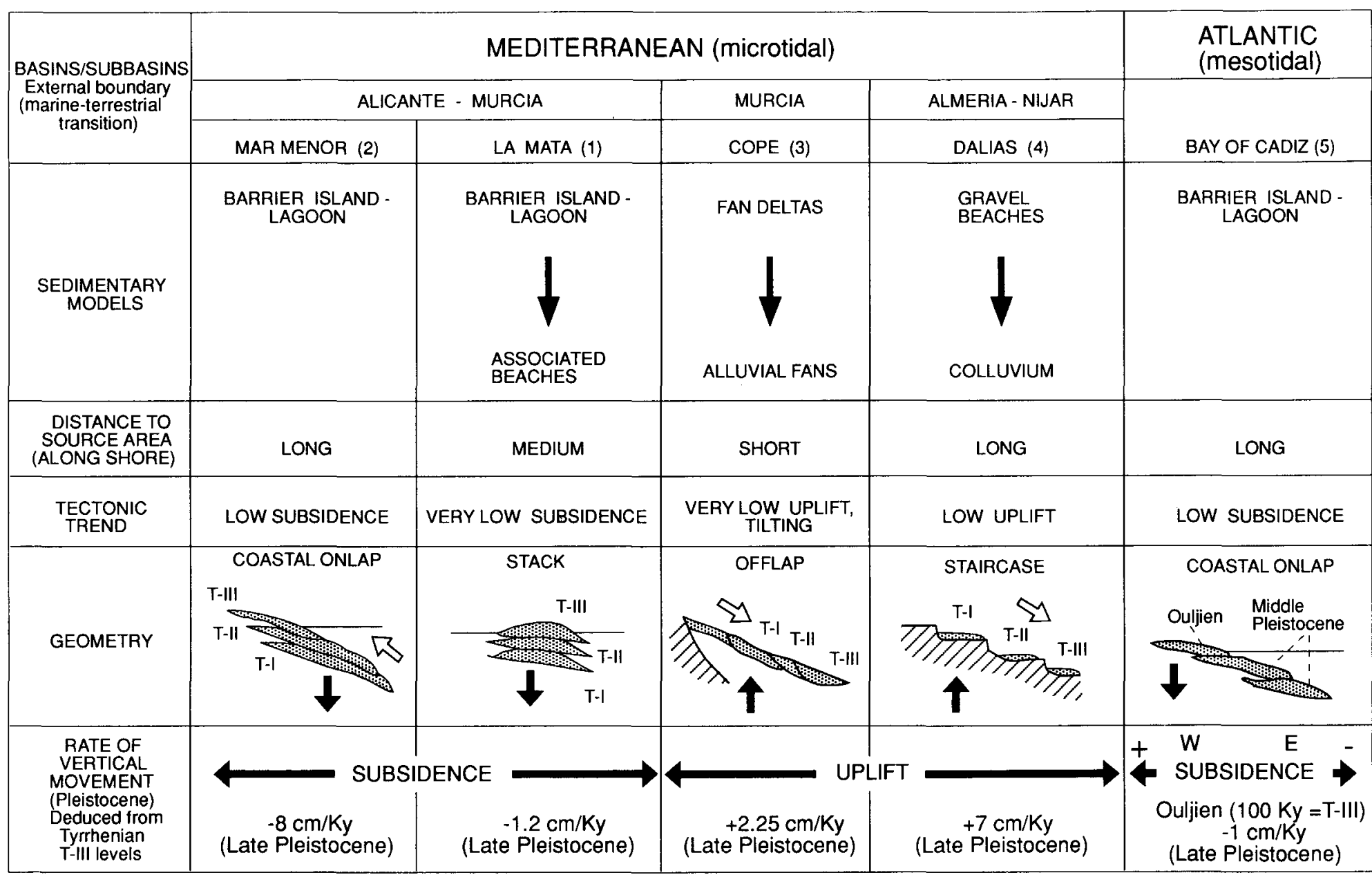


surfaces (lowstands), whereas sinking areas will favour the deposition of vertically stacked sequences with coastal onlap of beach-barrier systems deposits (Table 1).

The coastal dynamics factor largely depends on global sea-level changes which greatly influence the exchange of waters between the Atlantic and the Mediterranean. At present, a rapid current of surface Atlantic waters enters the Mediterranean forming anticyclonic vortexes which reach both the African and the Spanish coasts (Parrilla and Kinder, 1987). Maximum incursion of water coincides with periods of maximum insolation in the Mediterranean Sea, when increased evaporation produces differences in sea level on both sides of the Strait of Gibraltar.

The places in which the present circulation pattern reaches the coasts of the Alborán Sea closely coincide (Somoza et al., 1991) with those yielding the largest number of species of the warm fauna ( $S$. bubonius) and with those where they persisted longest (Almería and Alicante, localities 4 and 1, respectively in Fig. 1) during the Pleistocene.

The major point about this factor is that it defines and modifies the sedimentological features and organization of any unit being de- posited during a particular combination of "regional/global" sea-level and tectonic situations. It influences the rates of coastal accretion or retreat, setting up and reversals of littoral drift, erosional surfaces, and input of sediment available for the coastal budget.

Types of sequences of marine episodes according to the tectonic factor (episodes of the last 200,000 yr)

As previously discussed, the tectonic factor controls the disposition of each marine episode in the whole sequence and the type of coast which exists in a given highstand. The sedimentary pattern of marine episodes and their correlative sedimentary environments can be related with the trend of vertical movement in the last $200 \mathrm{kyr}$.

It is known that movements due to the tectonic factor are not constant with time. However, the data obtained from Tyrrhenian and Holocene deposits in the studied Spanish coast indicate that at least the general trends of uplift or subsidence have persisted during the last $200 \mathrm{kyr}$ (Goy et al., 1987a).

Rates of uplift or subsidence in the various areas were calculated using the marine deposits

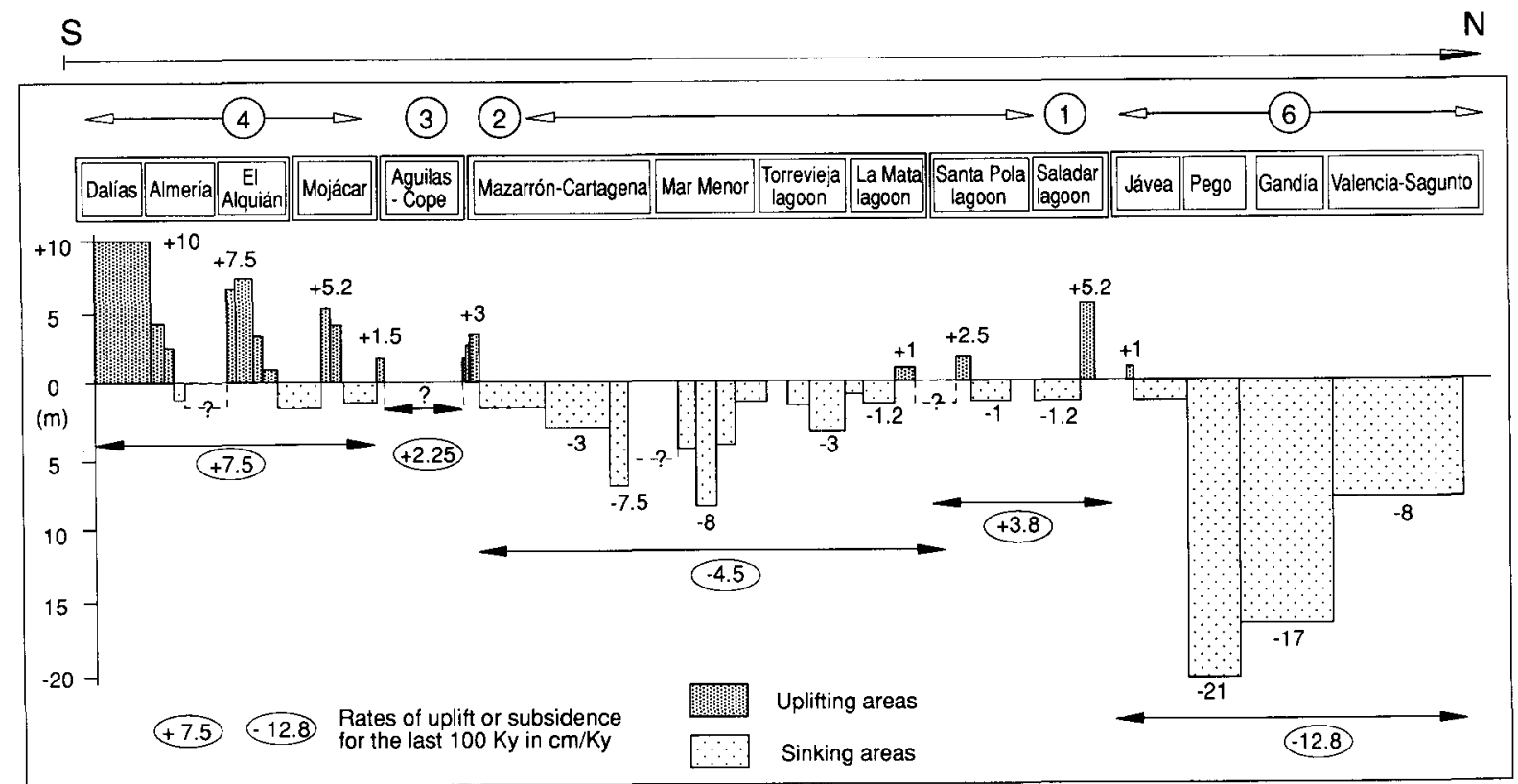

Fig. 3. Mean rates of uplift/subsidence in $\mathrm{cm} / \mathrm{kyr}$ for the last $100 \mathrm{kyr}$ deduced in the studied areas. 
of episode T-III (ca. $95 \mathrm{kyr}$, isotopic substage 5c). We chose this particular Tyrrhenian morphosedimentary unit because it is the best developed and the more continuous laterally.

We used the present altimetric position (positive or negative) of the Tyrrhenian-III episodes, defined either directly using isotopic dating or indirectly via cartographic or sequential correlation, to quantify rates of displacement. Plotting heights in a S-N line (Fig. 3) from Almería (locality 4 in Fig. 1, compressional setting) to Alicante and Valencia (locality 6 in Fig. 1, extensional regime) we can observe a decrease in the heights at which T-III episodes occur. Datum is present Mediterranean sea-level at Alicante.

Considering a reference height of $0 \mathrm{~m}$ for the episode T-III, average values of velocities of tectonic movements were observed to change from low uplift $(7.56 \mathrm{~cm} / \mathrm{kyr})$ in Almería or very low uplift $(2.25 \mathrm{~cm} / \mathrm{kyr})$ in Aguilas-Cope to low subsidence $(8 \mathrm{~cm} / \mathrm{kyr})$ in Mar Menor lagoon, very low subsidence $(1.2 \mathrm{~cm} / \mathrm{kyr})$ in La Mata and low subsidence (up to $12.8 \mathrm{~cm} / \mathrm{kyr}$ ) in the Oval of Valencia area. These values of vertical displacement are one order of magnitude less than those of modern tectonically-active areas (usually less than $200 \mathrm{~cm} / \mathrm{kyr}$ ) or those of areas with very active tectonics of the island-arc type (over 400 $\mathrm{cm} / \mathrm{kyr}$, Lajoie, 1986).

There is a close relationship between the calculated values of vertical displacement and the sedimentary models of marine deposits and their geometric pattern or stratigraphic architecture (Table 1).

Rates of vertical displacement greatly influence the relationship of marine and terrestrial deposits resulting from the alternation of highstands and lowstands.

In areas with low uplift rates (e.g. Almería) marine episodes occur as a staircase. Marine units were deposited during highstands and were separated by thin veneers of colluvial deposits formed during the intervening lowstands.

In areas with very low rates of uplift (Cope area, Murcia), highstand deposits are marine fan-deltas connected to ephemeral wadi-like rivers (ramblas) which prograde rapidly during flash floods but stay inactive and are reworked by coastal processes for most of the time. Alluvial streams generate alluvial fans during lowstands. In consequence, offlapping sequences of alternating fan-delta (highstand) and alluvial-fan (lowstand) deposits are generated. A common feature of the areas with very low uplift is the progradation of coastal deposits. This is interpreted as a result of the continuous reactivation of the fluvial network following the uplift of the continental zones.

In contrast, subsiding areas are characterized by the development of barrier islands and lagoons independent of sediment supply by rivers. Subsiding areas during Tyrrhenian III are found to the north (Fig. 1, Table 1) (Mar Menor, Torrevieja, La Mata, Santa Pola, Saladar, Pego and La Albufera de Valencia lagoons) and to the southwest (Cádiz) where lowlands are well represented. Depending upon the rate of subsidence, the successive highstand units exhibit three different geometric patterns reflected in the present-day morphology of the barrier island-lagoon systems.

Very low rates of subsidence $(1.2 \mathrm{~cm} / \mathrm{kyr})$ induce vertical stacking of beach ridges separated by gentle erosional surfaces (Torrevieja, La Mata, Santa Pola). Present morphologies are closed fresh-water lagoons with no exchange of water or sediment with the open sea. A Holocene beach occurs entrenched into in the relict Pleistocene beaches. Rates of subsidence during Holocene times were not high enough to allow drowning of the Pleistocene beaches and inundation of the lowlands areas behind the barrier. In the area of Cádiz, the very low regional rate of subsidence (1 $\mathrm{cm} / \mathrm{kyr}$ ) induced coastal onlap of Late Pleistocene deposits where this subsidence was higher (Bay of Cádiz) with the deposition of Ouljien (Tyrrhenian III) episodes being further inland than those of Middle Pleistocene age (Zazo et al., 1983).

The second pattern occurs in areas with low subsidence rates $(8 \mathrm{~cm} / \mathrm{kyr})$. The stratigraphic architecture consists of stacked retrogradational (onlapping) barrier islands which migrated inland over the lagoonal deposits. This is the case of Mar Menor where poorly-developed recent beaches overlie a submerged terrace made of consolidated marine deposits. The lagoon is con- 


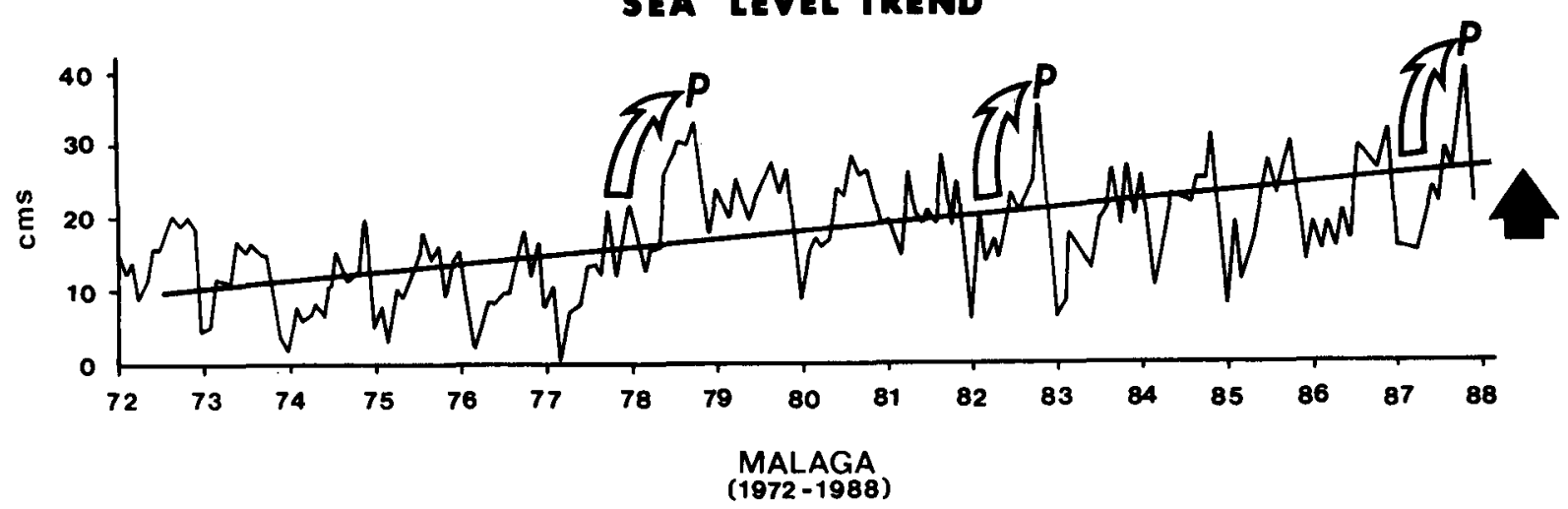

Fig. 4. Tide-gauge record (average levels) of Málaga harbour in the period 1972-1986 (I.E.O., 1991). Note the rising trend (10-15 $\mathrm{cm} / 15 \mathrm{yr})$ and the relation between the flow of Atlantic water masses into the Mediterranean $(P)$ and the abrupt rises of sea level.

nected to the open sea through the more subsiding areas (Díaz del Río et al., 1990) where overwash processes are also important.

The third pattern in subsiding areas occurs with relatively higher subsidence rates of 12.8 $\mathrm{cm} / \mathrm{kyr}$. Rates of subsidence measured in the Oval of Valencia (Fig. 2) are higher because of the extensional tectonic regime experienced during the Quaternary. Pleistocene marine deposits in this area extend from the inner shelf to the present shore (Goy et al., 1987b). Retrograding, Tyrrhenian marine episodes occur at depths ranging from 21 to $17 \mathrm{~m}$ (Dupré et al., 1988) in boreholes. Continued subsidence during the Holocene allowed the development of large beach-barriers and lagoonal peats. From a morpho-dymanic point of view, the area is unstable because the coastal complexes deposited during highstands are strongly controlled by fluctuations of sea level. The reason is that the consolidated Late Pleistocene deposits cannot act as a supporting platform for Holocene spits and barriers (as they do in areas with low rates of subsidence such as the Mar Menor) because they are too deep below sea level.

Types of sequences of marine episodes according to the Atlantic-Mediterranean water mass balance (episodes in the last $6 \mathrm{kyr}$ )

The intrusion of Atlantic water into the Mediterranean sea and the trajectory of the buoyant plume seems to have controlled the per- sistence of $S$. bubonius during the isotopic stages 7 and 5 in Almería and until the Last Interglacial in Alicante (Goy and Zazo, 1988; Zazo and Goy, 1989). But, in addition it also determined the areas with maximum rates of beach-ridge progradation in Almería and Alicante (Goy et al., 1986; Zazo et al., 1989) during the Holocene, which are related to the coastal segments where the anticyclonic-turning plume swept the coast.

Detail geomorphological analysis and dating of Holocene beach ridges on the coast of Almería revealed that the maxima of progradation took place during highstands $\left(\mathrm{H}_{1}, \mathrm{H}_{2}, \mathrm{H}_{3}\right)$ which, in turn, coincided with warmer periods and maximum input of Atlantic water (Somoza et al., 1991).

For more recent epoch, tide-gauge data collected between 1973 and 1988 (Instituto Español de Oceanografía, 1991) indicate an average rise of sea level of about $1 \mathrm{~cm} / \mathrm{yr}$ (Fig. 4). This figure is of the same order as rates frequently suggested for the coming years by some authors. As these rates were calculated in areas close to the Atlantic, we suggest that values measured in areas located more distal from the Straits of Gibraltar along the Mediterranean coast of Spain will be different.

\section{Conclusions}

Three main peaks representing global highstands of sea level in the Last Interglacial have been distinguished on the Spanish Mediterranean 
coast. The marine deposits (morpho-stratigraphic units) representative of these highstands contain the Tyrrhenian warm fauna including the typical S. bubonius: T-II, ca. $128 \mathrm{kyr}$ (isotopic substage 5e), T-III, ca. $95 \mathrm{kyr}$ (isotopic substage 5c) and T-IV, probably representative of isotopic substage 5a (ca. $80 \mathrm{kyr}$ ).

Several minor positive oscillations of sea level were distinguished inside each of these morphostratigraphic units. Three of them are included in the isotopic substage $5 \mathrm{e}$, which presumably lasted each ca. 10,500 years.

The three positive sea-level fluctuations $\left(\mathrm{H}_{1}\right.$ ca. 5100 yr B.P., $\mathrm{H}_{2}$ ca. 3500 yr B.P., $\mathrm{H}_{3}$ ca. 2400 yr B.P.) recorded on the Spanish coast during the Present Interglacial imply cycles which lasted 2500-1100 yr. If we compare these values with those deduced from the Last Interglacial, we conclude that, at present, we are within the first oscillation (duration $10,500 \mathrm{yr}$ ) of the first peak of sea-level highstand, which corresponds to an isotopic substage. Consequently, we should expect other positive oscillation(s) of sea level in the coming years.

As the tectonic factor greatly influences and modifies the effects of sea-level changes in the coastal areas of tectonically-active regions such as the Mediterranean, some conclusions can be drawn.

If, as suggested by some authors, the rate of sea-level rise for the coming years is about 1 $\mathrm{cm} / \mathrm{yr}$, these gradients are much higher than those reached by the tectonic factor in the Spanish coast for the last $100 \mathrm{kyr}$. Shoreface erosion and transgression with landward migration of barrier islands and lagoons will occur in subsiding areas, characterized by negative coefficients (Murcia-Alicante and Valencia), even with relatively low values of sea-level rise (less than 0.5 $\mathrm{cm} / \mathrm{yr}$ ). Intermediate values of sea-level rise $(0.5-1 \mathrm{~cm} / \mathrm{yr})$ will increase this transgressive trend. Thus, areas with subsidence rates in excess of $7.5 \mathrm{~cm} / \mathrm{kyr}$ (Mar Menor and Oval of Valencia, locality 6, Fig. 1) are those which are most menaced by transgression and erosion of barrier islands and lagoons both in the cases of stable and rising sea levels. The expected risks are smaller in areas with lower rates of subsidence ( $\mathrm{La}$ Mata,
Santa Pola, and Torrevieja lagoons) when a stable sea level is considered, but these will tend to be eroded in the case of a rise of sea level.

\section{Acknowledgements}

Supported by the Spanish DGICYT Projects PB88-0125 and PB89-0049; this is part of IGCP Project 274.

\section{References}

Abrantes, F., 1988. Diatom productivity peak and increased circulation during latest Quaternary: Alborán Basin (Western Mediterranean). Mar. Micropaleontol., 13: 7996.

Bardají, T., Civis, J., Dabrio, C.J., Goy, J.L., Somoza, L. and Zazo, C., 1986. Geomorfología y estratigrafía de las secuencias marinas y continentales de la Cuenca de Cope (Murcia, España). In: F. López Bermúdez and J.B. Thornes (Editors), Estudios sobre Geomorfología del Sur de España. I.G.U., Univ. Murcia y Bristol, pp. 11-16.

Bernat, M., Echailler, J.C. and Bousquet, J.C., 1982. Nouvelles datations Io-U sur des Strombes du dernier Interglaciaire en Mediterranée (La Marina, Espagne) et implications geologiques. C.R. Acad. Sci. Paris, 295-II: 10231026.

Brückner, H., 1986. Stratigraphy, evolution and age of Quaternary marine terraces in Morocco and Spain. Z. Geomorphol. N.F., 62: 83-101.

Cuerda, J., 1989. Los tiempos Cuaternarios en Baleares, D. Gral. de Cultura. Cons. Cult. Educ. Esp. Govern. Balear. Politécnica, Palma de Mallorca, $310 \mathrm{pp}$.

Díaz del Río, V., Somoza, L., Zazo, C. and Goy, J.L., 1990. The role of the relative sea level changes on the Quaternary Evolution of the Mar Menor (Murcia, España). Rapp. Comm. Int. Mer Medit., 32, p. 1.

Dupré, M., Fumanal, M.P., Sanjaume, E., Santisteban, C., Usera, J. and Viñals, M.J., 1988. Quaternary evolution of the Pego coastal lagoon (Southeastern Spain). Palaeogeogr., Palaeoclimatol., Palaeoecol., 68 (2-4): 291-300.

Goy, J.L. and Zazo, C., 1986. Synthesis of the Quaternary in the Almeria littoral, neotectonic activity and its morphologic features, eastern Betics, Spain. Tectonophysics, 130: 259-270.

Goy, J.L. and Zazo, C., 1988. Sequences of Quaternary marine levels in Elche Basin (Eastern Betic Cordillera, Spain). Palaeogeogr., Palaeoclimatol., Palaeoecol., 68: 301-310.

Goy, J.L., Rey, J., Díaz del Río, V. and Zazo, C., 1987b. Relación entre las unidades geomorfológicas cuaternarias del litoral y de la plataforma interna-media de Valencia (España): implicaciones paleogeográficas. Geol. Ambient. Orden. Territ. Valencia, 1987, Com., II, pp. 1369-1381.

Goy, J.L., Zazo, C., Bardaji, T. and Somoza, L., 1987a. Tyrrhenian and Holocene levels disposition in the southeastern Spanish littoral, related to the Quaternary compression. Bull. INQUA Neotectonics Com., 10: 12-19. 
Goy, J.L., Zazo, C., Dabrio, C.J. and Hillaire-Marcel, C., 1986. Evolution des systèmes de lagons-îles barrières du Tyrrhénien à l'actualité à Campo de Dalías (Almería, Espagne). ORSTOM Coll. Trav. Doc., 197: 169-171.

Goy, J.L., Zazo, C., Somoza, L., Dabrio, C.J., Bardají, T. and Silva, P.G., 1993. Evolution of Quaternary shorelines in the area connecting the Atlantic and the Mediterranean. Quat. Int.,in press.

Hillaire-Marcel, C., Carro, O., Causse, C., Goy, J.L. and Zazo, C., 1986. Th/U dating on "Strombus bubonius" bearing marine terraces in southeastern Spain. Geology, 14: 613-616.

Instituto Español de Oceanografía, 1991. Niveles medios y constantes armónicas en los puertos de la costa española. Inf. Técn. I.E.O.

Lajoie, K.R., 1986. Coastal tectonics. In: Studies in Geophysics. Natl. Acad. Press, Washington DC, pp. 95-124

Montenat, C., Ott d'Estevou, P. and Masse, P., 1987. Tectonic-sedimentary characters of the Betic Neogene Basins evolving in a crustal transcurrent shear zone (SE Spain). Bull. Cent. Rech. Explor. Prod. Elf Aquitaine, 11: 1-22.

Parrilla, G. and Kinder, T.H., 1987. Oceanografía física del Mar de Alborán. Bol. Inst. Esp. Oceanogr., 4: 133-136.

Somoza, L., 1989. El Cuaternario litoral entre Cabo de Palos y Guardamar del Segura (Murcia-Alicante). Evolución geodinámica en relación con las variaciones del nivel del mar. Thesis. Univ. Complutense, Madrid, 352 pp. (unpublished).

Somoza, L., Goy, J.L., Zazo, C., Bardají, T., Dabrio, C.J. and
Silva, P.G., 1991. Holocene sea-level highstands in the western Mediterranean (SE Spain). A computer statistical analysis of radiocarbon dating. MBSS Newsl., 13: 61-64.

Zazo, C., Dabrio, C.J. and Goy, J.L., 1991. Regional versus global factors controlling sea-level changes: A lesson for the past. Terra Abstr., 3, p. 2811.

Zazo, C. and Goy, J.L., 1989. Sea level changes in the Iberian Peninsula during the last 200,000 years. In: D. Scott, P. Pirazzoli and G. Honing (Editors), Late Quaternary Correlations and Applications. Kluwer, Deventer, 256, pp. 2739.

Zazo, C., Goy, J.L. and Dabrio, C.J., 1983. Medios marinos y marinos-salobres en la bahía de Cádiz durante el Pleistoceno. Mediterranea, 3: 29-52.

Zazo, C., Goy, J.L., Dabrio, C.J., Civis, J. and Baena, J., 1985. Paleogeografia de la desembocadura del Guadalquivir al comienzo del Cuaternario. Actas G.T.P.E.Q., pp. 461-472.

Zazo, C., Somoza, L., Goy, J.L. and Bardají, T., 1989. Evolution of the littoral dune systems from 120,000 years ago up to now (Valencia, Alicante, Murcia, Spain). In: Discussion Report on Coastal Dunes, Eur. Conf. Landscape Ecol. Impact on Climatic Change), pp. 1-11.

Zazo, C., Somoza, L., Goy, J.L. and Bardají, T., 1990. Controlling factors of the marine-continental relationships in the Quaternary deposits of the Atlantic and Mediterranean Betic littorals (Spain). Ext. Abstr. Int. Symp. Quaternary Shorelines: Evolution Processes and Future Changes, Annu. Meet. IGCP 274, La Plata, 1990, pp. $72-78$. 